\title{
The mid-Ludfordian Glaciation: a trigger for global changes in ocean chemistry and ecosystem overturns
}

\author{
J. FRÝDA ${ }^{1,2 *}$, O. LEHNERT ${ }^{1,3}$, M. JOACHIMSKI ${ }^{3}$, \\ P. MÄNNIK ${ }^{4}$ M. KUBAJKO ${ }^{2}$, M. MERGL ${ }^{1,5}$, J. FARKAS̆ ${ }^{1,6}$ \\ AND B. FRÝDOVÁ ${ }^{1}$ \\ ${ }^{1}$ Faculty of Environmental Sciences, Czech University of Life \\ Sciences Prague, Czech Republic (*correspondence: \\ bellerophon@seznam.cz) \\ ${ }^{2}$ Czech Geological Survey, Prague, Czech Republic \\ ${ }^{3}$ GeoZentrum Nordbayern, Friedrich-Alexander University \\ Erlangen-Nürnberg, Germany \\ ${ }^{4}$ Tallinn University of Technology, Inst. of Geology, Estonia \\ ${ }^{5}$ University of West Bohemia, Czech Republic \\ ${ }^{6}$ University of Adelaide, Dep. Earth Sci., Australia
}

Paleontological and geochemical studies over the last two decades show clearly that the Silurian ocean-climate system was highly dynamic as evidenced by large positive carbon isotope excursions (CIEs). The origin and primary triggers of these globally recognized CIEs, and their links to the global carbon cycle and/or coeval changes in paleoecosystems and palaeoclimate are controversial and highly disputed. One of the largest Phanerozoic events, the mid-Ludfordian CIE (MLCIE; +8 to $+12 \%$ in $\delta^{13} \mathrm{C}_{\text {carb }}$ ), is well documented in late Silurian marine carbonates. The MLCIE was preceded by a globally recognized sea-level fall and the Lau/Kozlowskii extinction (LKE) event. Surprisingly, climatic oscillations often accompagnying Paleozoic extinctions and CIEs, were hitherto not documented across the entire MLCIE [1].

Based on the first high-resolution geochemical records across the MLCIE $\left(\delta^{13} \mathrm{C}_{\text {carb }}, \delta^{13} \mathrm{C}_{\mathrm{org}}, \delta^{34} \mathrm{~S}_{\mathrm{py}}, \delta^{18} \mathrm{O}_{\text {apatite, }}\right.$ and redoxsensitive trace elements), we test how climatic oscillations were linked to global biotic, paleoenvironmental and redox changes. The $\delta^{18} \mathrm{O}_{\text {apatite }}$ records from three paleocontinents, including tropical and middle latitudinal areas, reveal a prominent positive anomaly of about $+3 \%$ starting just before the LKE. The onset of this global cooling (the mid Ludfordian glaciation) was associated with an eustatic sealevel fall and an anoxic/euxinic event followed by $\delta^{13} \mathrm{C}_{\mathrm{carb}}$, $\delta^{13} \mathrm{C}_{\mathrm{org}}$, and $\delta^{34} \mathrm{~S}_{\mathrm{py}}$ anomalies. New data from high latitudes across this anoxic/euxinic event, presumably caused by upwelling of oxygen-poor waters and associated with the LKE, together with tropical records [2] reflect a global extension of ocean anoxia. New data suggest that the mid Ludfordian glaciation triggered global changes in ocean chemistry and ecosystem overturns.

[1] Trotter et al. (2016), Palaeo3, 443, 34-48. [2] Bowman et al. (2019) Geology, 47, 968-972. 